\title{
STUDY OF THE REDUCTION PROCESS OF IRON IN LEACHATE FROM NICKEL MINING WASTE
}

\author{
A. B. Botelho Junior ${ }^{1 *}$, M. M. Jiménez Correa ${ }^{1}$, D. C. R. Espinosa ${ }^{1}$ and J. A. S. Tenório ${ }^{1}$ \\ ${ }^{1}$ University of São Paulo, Escola Politécnica, Department of Chemical Engineering, Av. Prof. Luciano Gualberto, \\ travessa 3, No. 380, 05508-010, São Paulo, SP, Brasil.
}

(Submitted: June 19, 2017 ; Revised: October 19, 2017 ; Accepted: January 3, 2018)

\begin{abstract}
A mechanism to convert Fe(III) to Fe(II) by a reduction process could be a solution to the problem of selective separation of metals in extraction processes by using the ion-exchange process. The aim of this research was to reduce $\mathrm{Fe}$ (III) to $\mathrm{Fe}$ (II) present in leachate from nickel mining waste. Reducing agents used were sodium dithionite and sodium metabisulfite. The potential was decreased in order to quantify the minimum reducing agent that was necessary for conversion. Reaction time, $\mathrm{pH}$, stirring speed and temperature were also studied. Results indicated dithionite was a better reducing agent than metabisulfite and complete conversion was possible by reducing the potential to $590 \mathrm{mV}$ at $\mathrm{pH} 0.5-2$ and $240 \mathrm{mV}$ at $\mathrm{pH} 2.5$. Stirring speed had no influence on the reduction process at 2 hours; however, conversion decreased after 24 hours, perhaps due to oxygen present in air. The analyses were conducted by ion chromatography and voltammetry.

Keywords: Sodium dithionite; Sodium metabisulfite; Reduction process; Ion exchange.
\end{abstract}

\section{INTRODUCTION}

Nickel is an important metal used in modern infrastructure. It plays a role in stainless steel (65\%), metal alloys $(\sim 20 \%)$, electric batteries and chemical applications $(\sim 9 \%)$. Nickel is found mainly as two types of ores: sulfide and laterite. Approximately $60 \%$ of all production comes from sulfide ores, while $70 \%$ of nickel resources are from laterite ones. This is due to the complexity of treating lateritic nickel ores compared to sulfide ores (Dalvi et al., 2004; British Geological Survey, 2008; Mudd, 2009; Crundwell et al., 2011).

The characteristics of lateritic ores strongly depend on their geological formation. The layers creating the lateritic structure are: ferricrete, with approximately $35 \% \mathrm{Fe}$; limonite with nearly $45 \% \mathrm{Fe}$ - the highest iron content among laterite layers -; nontronite, or smectite, presents in dryer climates, with almost $18 \% \mathrm{Fe}$; and saprolite, with almost $9 \% \mathrm{Fe}$ in dry areas and $10-25 \% \mathrm{Fe}$ in humid areas (Dalvi et al., 2004). The presence of iron content in lateritic nickel has great influence in terms of extraction processes (Crundwell et al., 2011).

As the nickel production rises annually, the amount of reserves has increased too, due to the improvement of mining technology, the extraction from new reserves, development of new process routes from known resources and the extraction of nickel from tailings or waste (Crowson, 2011; Miranda and Marques, 2016; Marta-Almeida et al., 2016; Kemp et al., 2016; Machado, 2007; Azam and Li, 2010).

Laterite processes used to extract metals are: the Caron process (pyrometallurgical process), HPAL or AL (high pressure acid leaching or acid leaching hydrometallurgical process) and RKEF (rotary kiln electric furnaces - pyro- and hydrometallurgical process). The liquor obtained from hydrometallurgical process can be purified by techniques of precipitation, solvent extraction and ion exchange (Dalvi et al., 2004; McDonald and Whittington, 2008; Crundwell et al., 2011).

\footnotetext{
*Correspondence: E-mail: amilton.junior@usp.br
} 
An ion exchange reaction may be defined as the reversible interchange of ions between a solid phase (the ion exchange resin, where cations and anions are fixed) and a solution phase, the ion exchanger being insoluble in the environment in which the exchange is carried out (Abrão 2014; Harland 1994). In recent years, researches have been carried out on ion-exchange process applied to hydrometallurgy (Coutinho et al., 1999; Alexandratos, 2009; Zainol and Nicol, 2009; Mendes and Martins, 2004; Mendes and Martins, 2005a; Mendes and Martins, 2005b; Riani, 2008).

Generally, extraction of nickel from laterites results in dissolution of iron compounds, which leads to a pregnant leach solution containing high concentrations of iron. Therefore, Fe(III) occupies more active sites of the resin than $\mathrm{Fe}(\mathrm{II})$, and the ion exchange is limited to $\mathrm{pH} 2$, because above it the iron precipitates which causes co-precipitation of other metals, unless the iron in solution is in the form of $\mathrm{Fe}$ (II) (Jiménez Correa et al., 2016). In order to improve efficiency in recovery of metals, the chemical reduction of $\mathrm{Fe}$ (III) to $\mathrm{Fe}(\mathrm{II})$ could be a solution for techniques of precipitation, ion exchange and solvent extraction.

Pourbaix's Diagram as in Fig. 1 shows areas where $\mathrm{Fe}(\mathrm{II})$ or $\mathrm{Fe}$ (III) are stable, which could give the opportunity to predict the existence of $\mathrm{Fe}$ (II) depending on $\mathrm{pH}$ and potential. Another problem of ion exchange processes at $\mathrm{pH}$ below 2 is the high presence of $\mathrm{H}^{+}$ions. These ions compete with metal ions for the functional groups of the ion exchange resin. However, when the $\mathrm{pH}$ value increases, the increasing presence of $\mathrm{OH}^{-}$ ions cause formation of hydroxyl complexes with metals. In other words, metals begin to precipitate, which is strongly related to $\mathrm{pH}$ and composition of the solution (Inamuddin and Luqman, 2012; Zainol and Nicol, 2009; Gode and Pehlivan, 2003).
Sodium dithionite (DS) is used for this process in kaolin - $\mathrm{Al}_{2} \mathrm{Si}_{2} \mathrm{O}_{5}(\mathrm{OH})_{4}$ - where brightness for use in paper coating is affected by Fe(III) (Cameselle et al., 1995; Ambikadevi and Lalithambika, 2000; Chandrasekhar and Ramaswamy, 2006; Bertolino et al., 2010). The species responsible for the reduction process is the bisulfite anion $\left(\mathrm{HSO}_{3}^{-1}\right)$, originated from dissociation of DS in aqueous solution. Bisulfite anion reacts with $\mathrm{Fe}(\mathrm{III})$ and, through a reduction process, results in $\mathrm{Fe}(\mathrm{II})$ (Cermak and Smutek, 1975).

The aim of this work is to develop a route to reduce $\mathrm{Fe}(\mathrm{III})$ to $\mathrm{Fe}(\mathrm{II})$ using sodium dithionite and sodium metabisulfite as reducing agents. During the study, synthetic iron sulfate solution was used. The parameters studied were: $\mathrm{pH}$ ( 0.5 to 2.5$)$, reaction time (30 to 240 minutes and 96 hours), stirring speed ( 0 to 200 $\mathrm{rpm})$, reducing agent concentration $\left(0.1\right.$ to $\left.1 \mathrm{~mol}^{\mathrm{L}} \mathrm{L}^{-1}\right)$, and temperature $\left(25\right.$ to $\left.60^{\circ} \mathrm{C}\right)$. After conditions were determined, an experiment was performed using synthetic multi-element solution in order to simulate the reduction process in leachate from nickel mining waste. This solution simulates the metal concentration of liquor from limonite after the acid leaching process, that was considered before as a waste due to the high concentration of iron, which interfered in traditional processes.

\section{MATERIALS AND METHODS}

\section{Solution Preparation}

The solution was prepared using iron sulfate octahydrate $\left(\mathrm{Fe}_{2}\left(\mathrm{SO}_{4}\right)_{3} .8 \mathrm{H}_{2} \mathrm{O}\right)$ with $18715.5 \mathrm{mg} \cdot \mathrm{L}^{-1}$ of $\mathrm{Fe}(\mathrm{III})$ (Cromoline). Reducing agents were sodium dithionite and sodium metabisulfite (CAAS - Casa Americana). All reagents were analytical grade. $\mathrm{A} \mathrm{Ag} /$

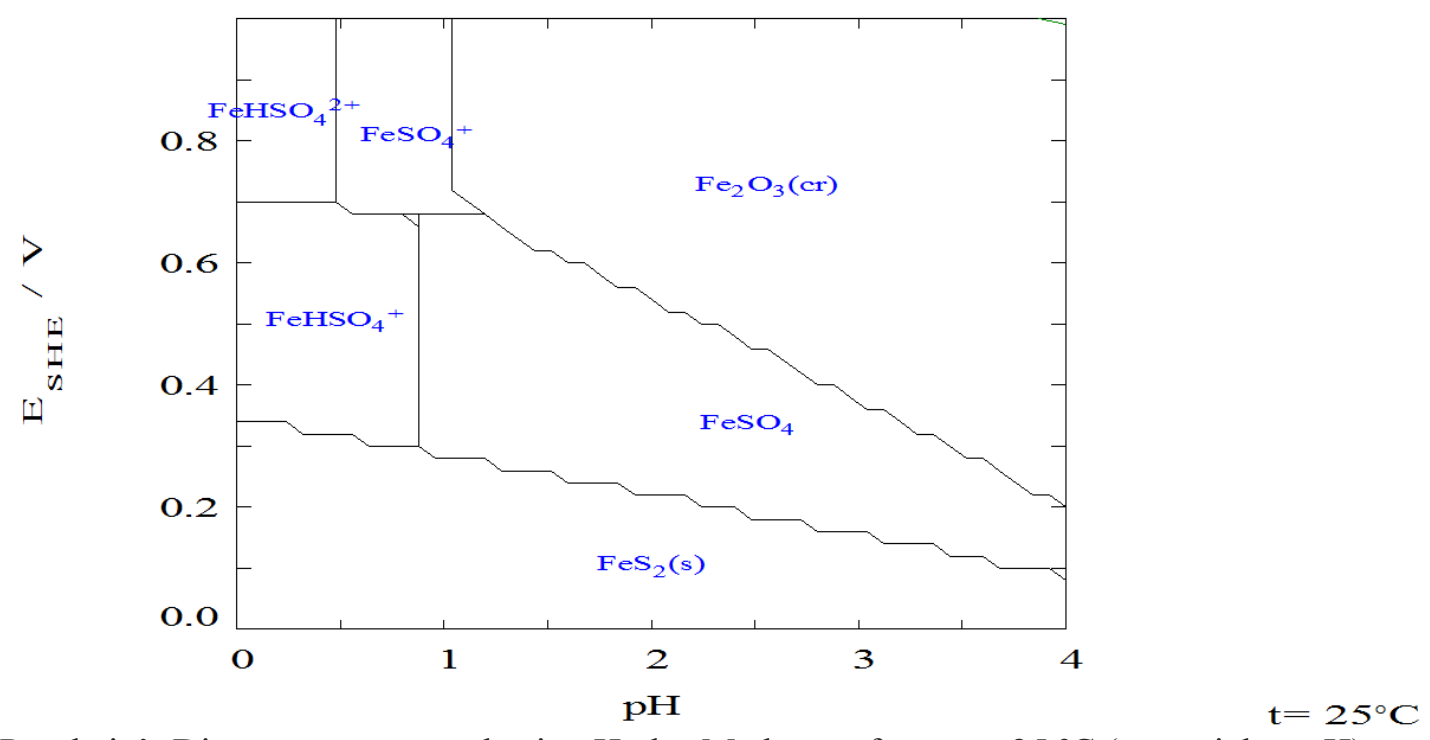

Figure 1. Pourbaix's Diagram constructed using Hydra-Medusa software at $25^{\circ} \mathrm{C}$ (potential vs $\mathrm{pH}$ ). 
$\mathrm{AgCl}$ (3 mol. $\left.\mathrm{L}^{-1}\right)$ SensoGlass electrode was used to measure the potential, which was adjusted using the equation given to compare with Pourbaix's Diagram (Jardim 2014):

$$
E=240 m V+E_{\text {meas }}
$$

\section{Study of pH Influence and Reaction Time}

These experiments were performed using reducing agents at a concentration of $0.5 \mathrm{~mol} . \mathrm{L}^{-1}$ and $25^{\circ} \mathrm{C}$. First, the influence of the reduction process between pH 0.5 to 2 in a range of 0 and 420 min was studied. The potentials studied were $840,740,690$ and $640 \mathrm{mV}$ to quantify the minimum of reducing agent needed to reduce $\mathrm{Fe}(\mathrm{III})$ to $\mathrm{Fe}(\mathrm{II})$. These experiments were conducted without stirring.

\section{Stirring Speed}

These tests were studied at 90, 150 and $200 \mathrm{rpm}$, $\mathrm{pH} 0.5$ and $640 \mathrm{mV}$. In the experiments of kaolin leaching using sodium dithionite, the agitation rate used was $90 \mathrm{rpm}$ to minimize the oxygen influence on the reduction process (Cameselle et al., 1995; Luz and Lins, 2008; Luz et al., 2010; Da Silva et al., 2011). These experiments were executed in and orbital shaker at $25^{\circ} \mathrm{C}$.

\section{Reducing Agent Concentration}

The reducing agent concentrations studied were 0.1 and 1 mol. $\mathrm{L}^{-1}$ to verify the effect on iron conversion in 2 hours and determine the consumption of reducing agents for various concentrations. The DS solution was prepared before the reducing process, because DS decomposes to sulfur elementary and sulfur dioxide at acidic pH (below 3) (Cermak and Smutek, 1975; Geoffroy and Demopoulos, 2009). The reducing agent behavior of $\mathrm{DS}$ is caused by decomposition to $\mathrm{HSO}_{3}^{-}$, where occurs at $\mathrm{pH} 5-7$, as exhibited in Equation 2 (Irwin, 2011). Bisulfite anion will reduce $\mathrm{Fe}(\mathrm{III})$ to $\mathrm{Fe}(\mathrm{II})$. The reaction between sodium dithionite and $\mathrm{Fe}$ (III) is presented in Equation 3 (Cermak and Smutek, 1975; Irwin, 2011; Chou et al., 2015; Luz and Lins, 2008).

$$
\begin{aligned}
& \mathrm{Na}_{2} \mathrm{~S}_{2} \mathrm{O}_{4}+3 \mathrm{H}_{2} \mathrm{O} \rightarrow \mathrm{NaHSO}_{4}+\mathrm{NaHSO}_{3}+4 \mathrm{H}^{+} \\
& \mathrm{S}_{2} \mathrm{O}_{4}^{-2}+2 \mathrm{Fe}^{+3} \rightarrow 2 \mathrm{SO}_{2}+2 \mathrm{Fe}^{+2}
\end{aligned}
$$

The study of the reduction process in 96 hours was performed using $1 \mathrm{~mol} . \mathrm{L}^{-1}$ reducing agent solution, as well as in all following experiments. In this experiment, it was possible to verify how reducing agents were influenced by oxygen for periods of times.

\section{Obtaining Total Fe(III) Reduction}

Using 1 mol. $\mathrm{L}^{-1}$ of reducing agent, it was possible to verify which potential was necessary to obtain total iron reduction at $\mathrm{pH} 0.5$ and 2.5. It was important to discover the minimum potential necessary to reduce all $\mathrm{Fe}(\mathrm{III})$, due to iron precipitation at potentials below $350 \mathrm{mV}$, as presented in Fig. 2, as well as other metals present in liquor.

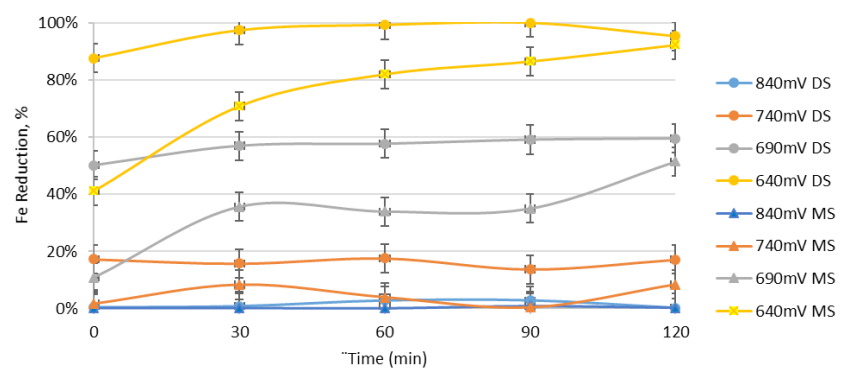

Figure 2. Fe(III) reduction percentage at $\mathrm{pH} 0.5$ using $\mathrm{DS}$ and $\mathrm{MS}$.

\section{Temperature}

The effect of temperature was studied between $25-60^{\circ} \mathrm{C}$. Sodium dithionite may degrade at high temperature, and there is greater dissolution of oxygen in the aqueous medium (Rinker et al., 1966; Cermak and Smutek, 1975). The experiments were realized at the potential verified before and $\mathrm{pH} 0.5$.

\section{Fe(III) Reduction in Synthetic Leachate from Nickel Mining Waste}

Table 1 presents the concentrations of metals in liquor of leachate from nickel mining waste. In order to study the chemical reduction of Fe(III), a synthetic solution was prepared with these metal concentrations to simulate the real waste. The best conditions determined in mono-element solution were applied in the multielement liquor, which was prepared using sulfate salts of each metal. All reagents were analytical grade.

\section{Analyses}

The experiments were performed to investigate the effect of reaction time on the reduction process,

Table 1. Metal concentrations in nickel synthetic liquor.

\begin{tabular}{cccccccccc}
\hline $\begin{array}{c}\text { Concentration } \\
\left(\mathbf{m g . L ^ { - 1 }}\right)\end{array}$ & $\mathbf{A l}$ & $\mathbf{C o}$ & $\mathbf{C r}$ & $\mathbf{C u}$ & $\mathbf{F e}$ & $\mathbf{M g}$ & $\mathbf{M n}$ & $\mathbf{N i}$ & $\mathbf{Z n}$ \\
\cline { 2 - 32 } & 4101.5 & 78.1 & 195.2 & 146.9 & 18713.5 & 7774.5 & 397.2 & 2434.2 \\
\hline
\end{tabular}


$\mathrm{pH}$ and potential. The analyses of $\mathrm{Fe}^{+3}$ and $\mathrm{Fe}_{\text {total }}$ were conducted using UV/vis spectrophotometry (Spectroquant Pharo 300), withdrawing an aliquot and diluting it 1:4 with $\mathrm{H}_{2} \mathrm{O}$ at $\mathrm{pH}$ 1.0. A sample of 0.1 $\mathrm{mL}$ was removed and $3 \mathrm{~mL}$ of 5-sulfosalicylic acid $10 \% \mathrm{w} / \mathrm{v}(\mathrm{SSA})$ and $97 \mathrm{~mL}$ deionized water added to quantify the $\mathrm{Fe}(\mathrm{III})$ concentration at $500 \mathrm{~nm}$; and $3 \mathrm{~mL}$ of $25 \% \mathrm{w} / \mathrm{w}$ ammonia added to quantify $\mathrm{Fe}_{\text {total }}$ (Karamanev et al., 2002; Paipa et al., 2005).

The following experiments were analyzed using ion chromatography with a $\mathrm{Fe}(\mathrm{II}) / \mathrm{Fe}$ (III) 882 Compact IC plus speciation column (Metrohm). In order to quantify the iron that was reduced in the liquor, a Voltametry Analyzer (797 VA Computace - Metrohn) was used.

\section{RESULTS}

\section{Study of pH Influence and Reaction Time}

Results of chemical reduction using sodium dithionite as reducing agent have been published (Botelho Junior et al., 2017). The following results are a comparison between sodium dithionite and sodium metabisulfite.

Fig. 3 presents chemical reduction of iron at $\mathrm{pH} 0.5$ from $840 \mathrm{mV}$ to $640 \mathrm{mV}$ using DS and MS as reducing agent. The first experiments were executed for 420 min; however it was observed that in $120 \mathrm{~min}$ the reaction was stabilized. As can be observed, using a potential of $640 \mathrm{mV}$ provided almost $95 \%$ of reduction. While it was possible to reach the maximum reduction percentage after $30 \mathrm{~min}$ for any potential with DS, 120 min were necessary using MS to reach the maximum value.

At $690 \mathrm{mV}$, conversion of $\mathrm{Fe}(\mathrm{III})$ reached $59.55 \%$ using DS and $51.43 \%$ using MS. At $740 \mathrm{mV}$, this conversion was $17.15 \%$ and $8.27 \%$ using DS and MS, respectively. At $840 \mathrm{mV}$ there was no conversion of $\mathrm{Fe}(\mathrm{III})$ to $\mathrm{Fe}(\mathrm{II})$.

These values were similar at $\mathrm{pH} 1.0$ and $\mathrm{pH} 1.5$ using both reducing agents. At pH 2.0, with $690 \mathrm{mV}$ the $\mathrm{Fe}$ (III) was converted $39.60 \%$ and almost $0 \%$ at $740 \mathrm{mV}$ and $840 \mathrm{mV}$, respectively, using MS; however, it was possible to obtain $90.84 \%$ of $\mathrm{Fe}(\mathrm{III})$ conversion at $640 \mathrm{mV}$ at the same $\mathrm{pH}$.

Using DS, the value is retained at $\mathrm{pH} 1$ and $\mathrm{pH} 1.5$ as presented in Fig. 2. At pH 2, with $690 \mathrm{mV} \mathrm{Fe(III)}$

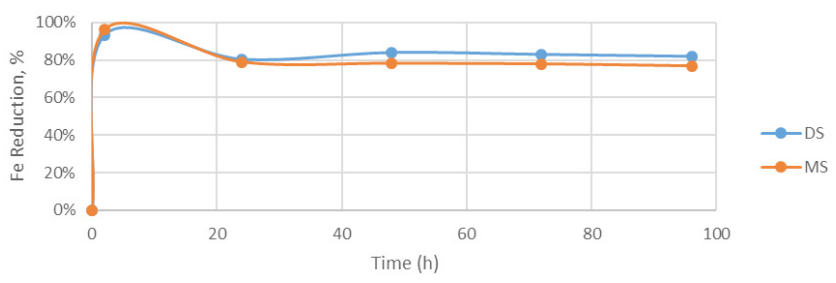

Figure 3. Percentage of Fe(III) reduction with time. was converted $40 \%$ and $20 \%$ with $740 \mathrm{mV}$. At $640 \mathrm{mV}$, the conversion stayed at 95\% (Botelho Junior et al., 2017).

At $\mathrm{pH} 2.5$ and $640 \mathrm{mV}$ using DS there was only $36.62 \%$ of $\mathrm{Fe}(\mathrm{III})$ reduction, and other potentials were below 10\%. Observing the Pourbaix's Diagram (Fig. 2), it can be possible to see that at $640 \mathrm{mV}$ and $\mathrm{pH}$ 2.5 iron is present as $\mathrm{Fe}_{2} \mathrm{O}_{3}$, and the $36.62 \%$ of iron reduction probably was possible due to the reducing agent action, but maybe $\mathrm{Fe}(\mathrm{II})$ could be oxidized to $\mathrm{Fe}(\mathrm{III})$ later. So, to have stable $\mathrm{Fe}(\mathrm{II})$ at $\mathrm{pH} 2.5$ it is necessary to decrease the potential below $640 \mathrm{mV}$.

The following experiments were executed at $\mathrm{pH}$ 0.5 and $640 \mathrm{mV}$. Results of the reduction process at $\mathrm{pH}$ between 0.5 to 2 shows no difference at $640 \mathrm{mV}$, either using DS or MS. In addition, nickel leach waste also has this $\mathrm{pH}$ value, therefore the option to study at $\mathrm{pH}$ 0.5 .

\section{Stirring Speed}

In order to examine the effect of stirring speed on the reduction process, the experiments were performed at 90, 150 and 200rpm using an orbital shaker. Despite the references of the kaolin reducing process (Da Silva et al., 2011; Martínez-Luévanos et al., 2011; Tuncuk et al., 2013), the stirring speed had no influence on the reduction process in this study and there was no difference in percentage of chemical reduction.

In addition, Cameselle et al. (1995) used a biological process for reducing iron from kaolin. It was verified that agitation had the least effect between 100-300 rpm, and the stirring speed was found to be enough to maintain kaolin in suspension avoiding mass transfer problems. In this work, with no presence of solids and mass transfer is not a problem, this allowed more choise of agitation rate. Ion exchange processes in batch experiments were performed at $200 \mathrm{rpm}$ to increase contact between resin and metals in solution. So, the agitation rate was maintained at $200 \mathrm{rpm}$ in the following experiments.

\section{Reducing Agent Concentration}

Reducing agent solution was prepared to be used to decrease the potential of the iron solution. Using reducing agent concentrations of $0.1 \mathrm{~mol}^{-\mathrm{L}^{-1}}$ and 1 mol.L $L^{-1}$ no difference was verified in the reduction process. The conversion was the same at all reducing agent concentrations studied over 2 hours, when the potential used as reference was $640 \mathrm{mV}$ and the only difference observed was the amount of reducing agent solution spent. Using 0.1 mol.L $\mathrm{L}^{-1}$, the proportion of DS solution:Fe solution was $2: 1$, while MS solution:Fe solution was $5: 1$. Using 1 mol.L ${ }^{-1}, 7 \%$ of the final solution was DS solution, while using MS it was 46\%. 
Nickel laterite waste has valuable metals in low concentration, which is the case of cobalt with 78.1 mg. $\mathrm{L}^{-1}$ while iron has $18713.5 \mathrm{mg} . \mathrm{L}^{-1}$. Using 0.1 mol.L $L^{-1}$ of DS or MS would dilute these metals to low concentrations, which would make the ion exchange process difficult and expensive. Thereby, the following experiments were carried out using the reducing agent concentration of $1 \mathrm{~mol} . \mathrm{L}^{-1}$.

Using a concentration of $1 \mathrm{~mol} . \mathrm{L}^{-1}$, an experiment was performed at $640 \mathrm{mV}$ in order to study the influence of days (96 hours) on the reduction process (Fig. 3). Whereas $420 \mathrm{~min}$ still gave the maximum iron reduction, after 24 hours the percentage of reduction drops from $96 \%$ to $80 \%$, with either DS or MS, and then this percentage stabilizes over 96 hours.

The potential (Fig. 4) decreased from $640 \mathrm{mV}$ to $620 \mathrm{mV}$ in the first 2 hours due to the reduction process. After 24 hours, the potential increased to $660 \mathrm{mV}$ and remained there for 96 hours. The oxygen might have had an influence as oxidizing agent only for the first 24 hours, but after that no effect was noticed on the process

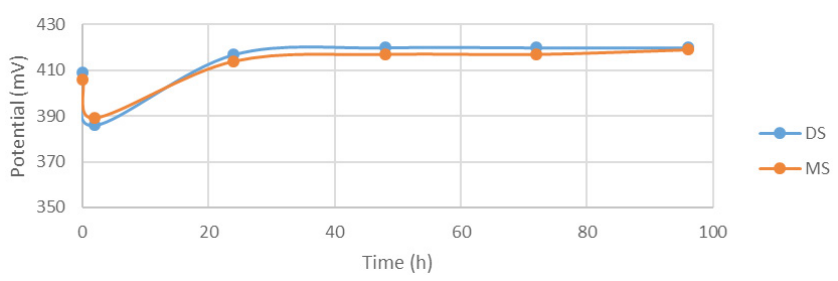

Figure 4. Potential (mV) over the 96 hours.

\section{Obtaining Total Fe(III) Reduction}

Using 1 mol.L $\mathrm{L}^{-1}$ of DS and MS an experiment was made in order to quantify the potential where the total reduction of $\mathrm{Fe}(\mathrm{III})$ would occur. At $\mathrm{pH} 0.5$, it was verified that $590 \mathrm{mV}$ was the minimum potential to fully reduce $\mathrm{Fe}(\mathrm{III})$, using both reducing agents. At $590 \mathrm{mV}$, observed in Fig. 1, iron is present as Fe(II). At $\mathrm{pH} 2.5$ a potential of $240 \mathrm{mV}$ was necessary using DS, however it was not possible using MS, where a limiting factor of $240 \mathrm{mV}$ was found.

Another factor to be considered was the control of $\mathrm{pH}$ in the reduction process at $\mathrm{pH} 2.5$, that was vital to the process. At $\mathrm{pH}$ below 2, this control was not necessary.

\section{Temperature}

The effect of temperature was studied. Using the total iron reduction result obtained, temperatures of 35 , 45 , and 60 were tested comparing with $25^{\circ} \mathrm{C}$ results. Fig. 5 demonstrates the results in percentage of iron reduction and temperatures, respectively. A decrease was observed of $5 \%$ between $25^{\circ} \mathrm{C}(100 \%)$ and $35^{\circ} \mathrm{C}$ ( $94.8 \%$ and $94.9 \%$ to DS and MS, respectively), which

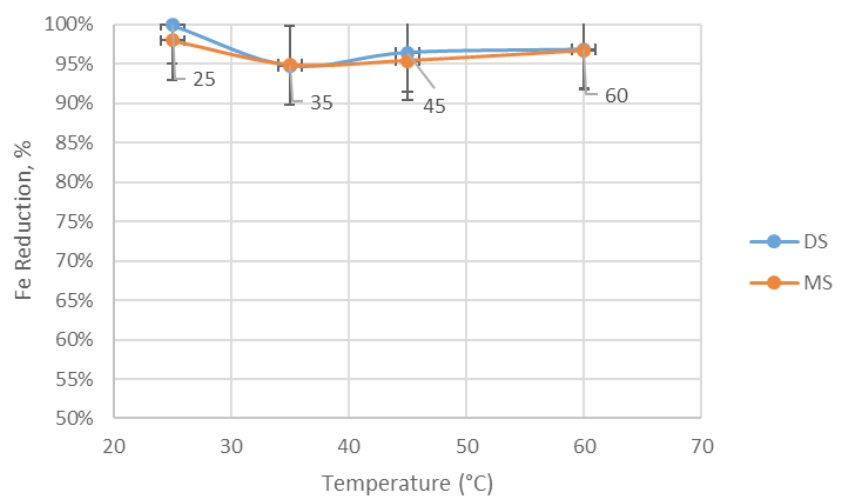

Figure 5. Percentage of Fe(III) reduction according to temperature.

it maintains at $45^{\circ} \mathrm{C}$ and $60^{\circ} \mathrm{C}$. So, it may be deduced that temperature has an influence on the reduction process, decreasing $\mathrm{Fe}(\mathrm{III})$ conversion, and $25^{\circ} \mathrm{C}$ was found to provide the best results. It is plausible to attribute this to decomposition of DS and MS at temperatures higher than $25^{\circ} \mathrm{C}$. The decrease of Fe(III) conversion might also be caused by an increase in oxygen dissolution while the temperature increased (Cermak and Smutek, 1975).

\section{Fe(III) Reduction in Synthetic Leachate from Nickel Mining Waste}

The optimum parameters determined before are: $590 \mathrm{mV}, 2$ hours, $25^{\circ} \mathrm{C}$ and $200 \mathrm{rpm}$, using DS. Using voltametry to determine $\mathrm{Fe}$ (II) and $\mathrm{Fe}_{\text {total }}$, it is possible to quantify $\mathrm{Fe}(\mathrm{III})$ ions in multi-element solution. With these parameters, $70 \%$ iron conversion was possible. The decrease in chemical reduction in the multi-element compared to the mono-element solution may be caused by the presence of other metals in the solution, which could compete with iron in the reduction process. In order to increase $\mathrm{Fe}$ (III) conversion, the potential was decreased to $490 \mathrm{mV}$, where it was possible to verify $77 \%$ of reduction and precipitate formation.

An experiment was performed at $240 \mathrm{mV}$, that gave $78.5 \%$ of iron conversion, but all copper in solution precipitated. Using SEM (scanning electron microscope) and EDS (energy-dispersive X-ray spectroscopy) it was possible to verify which elements were present in the precipitate. Fig. 6 and Fig. 7 present the SEM image and spectrum of the precipitate formed. It is possible to verify copper and sulfur in the solid.

The SEM image (Fig. 6) shows that copper sulfide is obtained by decreasing the potential of solution to $240 \mathrm{mV}$. Fig. 7 makes it clear that only copper among all metals present in the synthetic solution was precipitated with sulfur. Fig. 8 presents Pourbaix's Diagram of copper, and at $240 \mathrm{mV}$ and $\mathrm{pH} 0.5$ it is possible to verify that copper and sulfur precipitate 


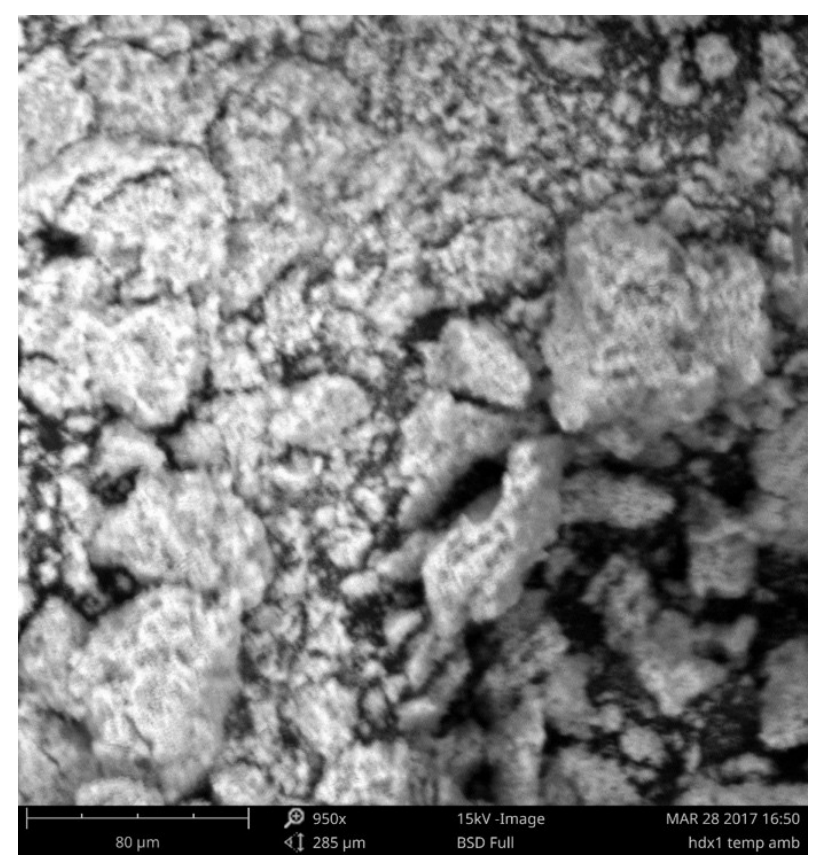

Figure 6. SEM image of precipitate formed in $240 \mathrm{mV}$ experiment. in these conditions. So, $590 \mathrm{mV}$ is the limit that it is possible to reduce the potential for nickel laterite leach. Besides in Fig. 1, the presence of iron was not verified in the precipitate.

\section{DISCUSSION}

Based on the results obtained in this study, the parameters to reduce $\mathrm{Fe}$ (III) to $\mathrm{Fe}$ (II) were established; the reduction process using DS had same results at the potentials studied at $\mathrm{pH} 0.5-2$, where it was to possible

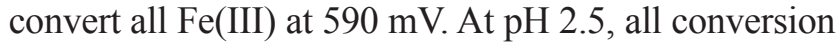
was possible at $240 \mathrm{mV}$. The reaction reached equilibrium in $120 \mathrm{~min}$. Stirring speed had no influence up to $200 \mathrm{rpm}$, but the conversion was decreased after 24 hours. This may have been caused by oxygen present in air. Oxygen is an oxidant that reacted with the reduction agent in solution, decreasing the reducing process. However, between 24 and 96 hours there was no decrease of iron conversion. The potential of the solution increased, indicating oxidant action.

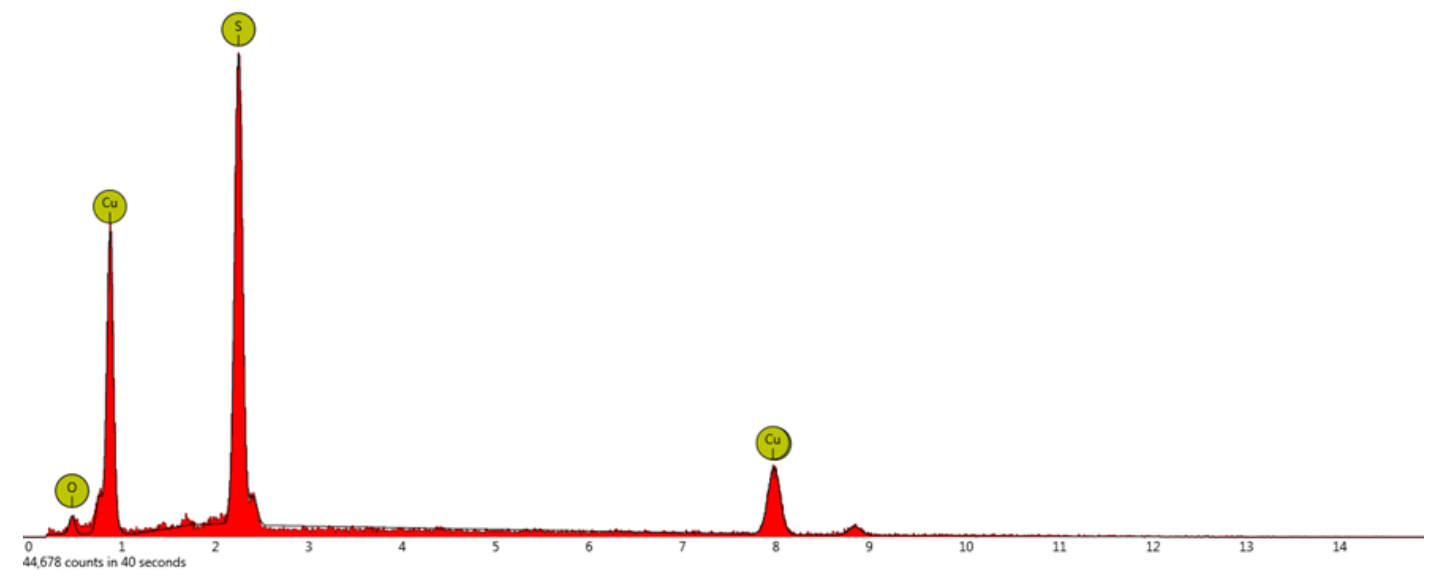

Figure 7. Spectrum of the precipitate formed in the $240 \mathrm{mV}$ experiment.

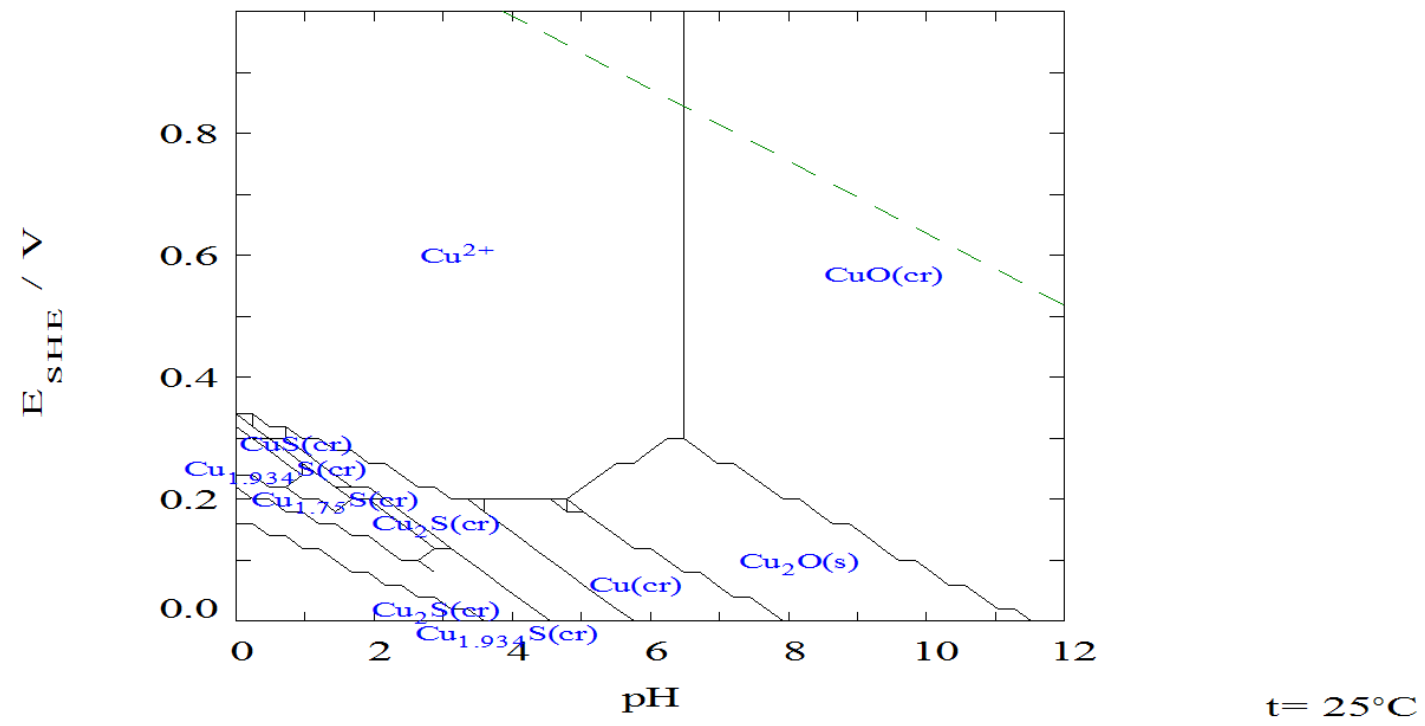

Figure 8. Pourbaix's Diagram of copper constructed using Hydra-Medusa software at $25^{\circ} \mathrm{C}$ (potential vs pH). 
Experiments carried out in order to study the influence of temperature showed that the reduction process efficiency decreased at temperatures above $25^{\circ} \mathrm{C}$. This could be due to degradation of DS and MS at the temperatures studied. Another factor that should be considered is oxygen adsorption in the solution when temperature increase.

Studies of a synthetic solution of nickel laterite leach waste showed that the potential limit was 590 $\mathrm{mV}$; if the potential decreased more, copper would precipitate.

\section{CONCLUSION}

The experimental work described demonstrated how to reduce iron in liquor of nickel laterite, but this value was limited by a potential of $590 \mathrm{mV}$. At potentials below $590 \mathrm{mV}$, it was possible to form precipitate, and at $240 \mathrm{mV}$ all copper precipitated. Sodium dithionite was a stronger reducing agent than sodium metabisulfite. In liquor, it was not possible to use MS as reducing agent, because the consumption of MS was higher to arrive at $590 \mathrm{mV}(380 \mathrm{~mL}$ of MS 1 mol.L $\mathrm{L}^{-1}$ for each $100 \mathrm{~mL}$ of liquor) compared to DS (27 $\mathrm{mL}$ of DS $1 \mathrm{~mol}^{-1}$ for each $100 \mathrm{~mL}$ of liquor). The importance of this study was that reducing iron could improve the recovery of metals by an ion exchange process, because $\mathrm{Fe}(\mathrm{III})$ precipitates at $\mathrm{pH}$ above 2 and occupies more active sites of the resin than Fe(II). Thus, it was feasible using this technique to recover more metals from liquor with $\mathrm{Fe}(\mathrm{II})$ than as $\mathrm{Fe}(\mathrm{III})$.

\section{ACKNOWLEDGEMENTS}

Authors would like to thank the Sao Paulo Research Foundation (Fundação de Amparo à Pesquisa do Estado de São Paulo) FAPESP/Capes - grants 2012/51871-9 and 2016/05527-5 for the financial support

\section{REFERENCES}

Abrão, A., Operações De Troca Iônica, São Paulo: Instituto de Pesquisas Energéticas e Nucleares CNEN/SP (2014).

Alexandratos, S.D., Ion-Exchange Resins: A Retrospective from Industrial and Engineering Chemistry Research. Industrial \& Engineering Chemistry Research, 48, 388-398 (2009). Available at: http://dx.doi.org/10.1021/ie801242v.

Ambikadevi, V.R. and Lalithambika, M., Effect of organic acids on ferric iron removal from ironstained kaolinite. Applied Clay Science, 16(3-4), 133-145 (2000).
Azam, S. and Li, Q., Tailings dam failures: A review of the last one hundred years. Geotechnical News, 28(4), 50-53 (2010).

Bertolino, L.C.; Rossi, A.M.; Scorzelli, R.B.; Torem, M.L., Influence of iron on kaolin whiteness: An electron paramagnetic resonance study. Applied Clay Science, 49(3), 170-175 (2010). Available at: http://dx.doi.org/10.1016/j.clay.2010.04.022.

Botelho Junior, A.B.; Jimenez Correa, M.M.; Espinosa, D.C.R.; Tenório, J.A.S., Chemical Reduction of Fe(III) in Nickel Lateritic Wastewater to Recover Metals by Ion Exchange. In TMS (The Minerals, Metals \& Materials Society). pp. 467-472 (2017). Available at: http://link.springer. com/10.1007/978-3-319-52392-7\%0Ahttp://link. springer.com/10.1007/978-3-319-52192-3_45.

British Geological Survey, Nickel. 'Natural Environment Research Council, pp.1-24 (2008).

Cameselle, C.; Núñez, M.J.; Lema, J.M.; Pais, J., Leaching of iron from kaolins by a spent fermentation liquor: Influence of temperature, $\mathrm{pH}$, agitation and citric acid concentration. Journal of Industrial Microbiology, 14(3-4), 288-292 (1995).

Cermak, V. and Smutek, M., Mechanism of decomposition of dithionite in aqueous solutions. Collection of Czechoslovak Chemical Communications, 40(11), 3241-3264 (1975).

Chandrasekhar, S. and Ramaswamy, S., Iron minerals and their influence on the optical properties of two Indian kaolins. Applied Clay Science, 33(3-4), 269-277 (2006).

Chou, Y.H.; Yu, J.H.; Liang, Y.M.; Wang, P.J.; Li, C.W.; Chen, S.S., Recovery of $\mathrm{Cu}(\mathrm{II})$ by chemical reduction using sodium dithionite: Effect of $\mathrm{pH}$ and Ligands. Water Science and Technology, 141, 183-188 (2015).

Coutinho, F.M.B., Rezende, S.M. and Barbosa, C.C.R., Resinas quelantes amidoxímicas. Polímeros, 9(4), 129-135 (1999).

Crowson, P.C.F., Mineral reserves and future minerals availability. Mineral Economics, 24(1), 1-6 (2010).

Crundwell, F.K.; Moats, M.S.; Ramahandran, V.; Robinson, T.G.; Davenport, W.G., Extractive Metallurgy of Nickel, Cobalt and PlatinumGroup Metals, Oxford: Elsevier (2011). Available at: http://linkinghub.elsevier.com/retrieve/pii/ B9780080968094100012.

Dalvi, A.D., Bacon, W.G. and Osborne, R.C., The Past and the Future of Nickel Laterites. PDAC 2004 International Convention, Trade Show \& Investors Exchange, pp.1-27 (2004).Toronto: The prospectors and Developers Association of Canada.

Geoffroy, N. and Demopoulos, G.P., Reductive precipitation of elemental selenium from selenious acidic solutions using sodium dithionite. Industrial and Engineering Chemistry Research, 48(23), 10240-10246 (2009). 
Gode, F. and Pehlivan, E., A comparative study of two chelating ion-exchange resins for the removal of chromium(III) from aqueous solution. Journal of Hazardous Materials, 100(1-3), 231-243 (2003).

Harland, C.E., Ion Eschange: Theory and Practice, The Royal Society of Chemistry (1994)..

Inamuddin \& Luqman, M., Ion Exchange Technology I, Springer (2012).

Irwin, S., A Comparison of the Use of Sodium Metabisulfite and Sodium Dithionite for Removing Rust Stains from Paper. In The Book and Paper Group Annual. pp. 37-46 (2011).

Jardim, W.F., Medição e interpretação de valores do potencial redox (Eh) em matrizes ambientais. Química Nova, 37(7), 1233-1235 (2014). Available at: http://www.scielo.br/scielo.php?script=sci arttext\&pid $=$ S0100-40422014000700020\&lng=en $\& n r m=$ iso \&tlng $=\mathrm{pt}$.

Jiménez Correa, M.M.; Aliprandini, P.; Tenório, J.A.S.; Espinosa, D.C.R., Precipitation of Metals From Liquor Obtained in Nickel Mining. Rewas 2016: Towards Materials Resource Sustainability, pp.333-338 (2016).

Karamanev, D.G., Nikolov, L.N. and Mamatarkova, V., Rapid simultaneous quantitative determination of ferric and ferrous ions in drainage waters and similar solutions. Minerals Engineering, 15(5), 341-346 (2002).

Kemp, D., Worden, S. and Owen, J.R., Differentiated social risk: Rebound dynamics and sustainability performance in mining. Resources Policy, 50, 1926 (2016). Available at: http://dx.doi.org/10.1016/j. resourpol.2016.08.004.

Kossoff, D.; Dubbin, W.E.; Alfredsson, M.; Edwards, S.J.; Macklin, M.G.; Hudson-Edwards, K.A., Mine tailingsdams: Characteristics, failure, environmental impacts, and remediation. Applied Geochemistry, 51, 229-245 (2014). Available at: http://dx.doi. org/10.1016/j.apgeochem.2014.09.010.

Luz, A.B. da and Lins, F.A.F., Rochas \& Minerais Industriais: Usos e Especificações (2008) Available at: http://www.cetem.gov.br/files/docs/livros/2008/ Rochas Min.Ind.2a edicao (Adao e F.Lins).pdf.

Luz, A.B. da, Sampaio, J.A. and França, S.C.A., Tratamento de minérios $5^{\mathrm{a}}$ edição., Rio de Janeiro (2010).

Machado, W.G.D.F., Monitoramento de barragens de contenção de rejeitos da mineração. Doctoral Thesis, Universidade de São Paulo (2007).

Marta-Almeida, M.; Mendes, R.; Amorim, F.N.; Cirano, M.; Dias, J.M., Fundão Dam collapse: Oceanic dispersion of River Doce after the greatest Brazilian environmental accident. Marine Pollution Bulletin, 112(1-2), 359-364 (2016). Available at: http://linkinghub.elsevier.com/retrieve/pii/ S0025326X16306038.
Martínez-Luévanos, A.; Rodríguez-Delgado, M.G.; Uribe-Salas, A.; Carrillo-Pedroza, F.R.; OsunaAlarcón, J.G., Leaching kinetics of iron from low grade kaolin by oxalic acid solutions. Applied Clay Science, 51(4), 473-477 (2011). Available at: http://dx.doi.org/10.1016/j.clay.2011.01.011.

McDonald, R.G. and Whittington, B.I., Atmospheric acid leaching of nickel laterites review Part I. Sulphuric acid technologies. Hydrometallurgy, 91(1-4), 56-69 (2008).

Mendes, F.D. and Martins, A.H., Recovery of nickel and cobalt from acid leach pulp by ion exchange using chelating resin. Minerals Engineering, 18(9), 945-954 (2005a).

Mendes, F.D. and Martins, A.H., Selective nickel and cobalt uptake from pressure sulfuric acid leach solutions using column resin sorption. International Journal of Mineral Processing, 77(1), 53-63 (2005b).

Mendes, F.D. and Martins, A.H., Selective sorption of nickel and cobalt from sulphate solutions using chelating resins. International Journal of Mineral Processing, 74(1-4), 359-371 (2004).

Miranda, L.S. and Marques, A.C., 2016. Hidden impacts of the Samarco mining waste dam collapse to Brazilian marine fauna - an example from the staurozoans (Cnidaria). Biota Neotropica, 16(2), pp.1-3. Available at: http://dx.doi. org/10.1590/1676-0611-BN-2016-0169.

Mudd, G.M., Nickel Sulfide Versus Laterite: The Hard Sustainability Challenge Remains. 48th Conference of Metallurgists, (August 2009), pp.1-10 (2009).

Paipa, C.; Mateo, M.; Godoy, I.; Poblete, E.; Toral, M.I.; Vargas, T., Comparative study of alternative methods for the simultaneous determination of $\mathrm{Fe}^{+3}$ and $\mathrm{Fe}^{+2}$ in leaching solutions and in acid mine drainages. Minerals Engineering, 18(11), 1116-1119 (2005).

Riani, J.C., 2008. Utilização de resinas de troca-ionica em efluentes de galvanoplastia., p.117.

Rinker, R.G. Gordon, T. P., Mason, D. M., Sakaida, R. R., \& Corcoran, W. H., Kinetics and mechanism of the air oxidation of the dithionite ion in aqueous solution. The Journal of Physical Chemistry, 64(5), 573-581 (1960).

Da Silva, F.A.N.G.; Garrido, F.M.S.; Medeiros; M.E., Alvejamento químico de caulins brasileiros: Efeito do potencial eletroquímico da polpa e do ajuste do pH. Quimica Nova, 34(2), 262-267 (2011).

Tuncuk, A., Ciftlik, S. and Akcil, A., Factorial experiments for iron removal from kaolin by using single and twostep leaching with sulfuric acid. Hydrometallurgy, 134-135, 80-86 (2013). Available at: http://dx.doi. org/10.1016/j.hydromet.2013.02.006.

Zainol, Z. and Nicol, M.J., Ion-exchange equilibria of $\mathrm{Ni}^{2+}, \mathrm{Co}^{2+}, \mathrm{Mn}^{2+}$ and $\mathrm{Mg}^{2+}$ with iminodiacetic acid chelating resin Amberlite IRC 748. Hydrometallurgy, 99(3-4), 175-180 (2009). Available at: http://dx.doi.org/10.1016/j. hydromet.2009.08.004. 